\title{
Covid-19 Pandeminin Sağlık Çalışanlarında Vicdani Zekânın Vicdan Algısı Üzerindeki Etkisi
}

The Effect of Conscientious Intelligence on the Perception of Conscience in Healthcare Professionals During the Covid-19 Pandemic Process

\author{
Ali ARSLANOĞLU ${ }^{1}$, Döne TÜTÜNCÜ², Aylin Günay ATALI ${ }^{3}$, Güven BEKTEMÜR ${ }^{4}$
}

\begin{abstract}
ÖZ
Vicdan sağlık çalışanlarını yanlış yapmaya karşı uyaran, rehberlik eden önemli bir kavramdır. $\mathrm{Bu}$ bağlamda sağlık çalışanlarında vicdanın araştırılması önemlidir. Çalışmanın amacı, sağlık çalışanlarında vicdani zekânın vicdan algısı üzerindeki etkisini değerlendirmektir. Araştırmanın örneklemini Türkiye'de görev yapan 389 sağlık çalışanı oluşturmaktadır. Araştırmada daha önceden geçerlilik ve güvenilirliğgi yapılan ölçeklerden oluşan anket kullanılmıştır. Ölçeklerin güvenirliği Cronbach Alpha yöntemi ile test edilmiştir. Verilerin analizinde SPSS Programı kullanılmıştır. Verilerin analizinde Pearson korelasyon, ANOVA Testi, t-Testi ve Regresyon Analizi kullanılmıştır. Araştırmada vicdani zekâ ve vicdan algısı ortalamalarına göre cinsiyet ve eğitim durumu açısından anlamlı bir farklılık bulunmamıştır. Öte yandan medeni durum ve meslek grupları açısından anlamlı bir farklılık gözlemlenmiştir. Yine vicdani zekâ ve vicdan algısı ortalamalarına göre yaş önemli bir belirleyici olarak belirlenmiş olup, literatürde farklı çalışmalar bulunmaktadır. Çalışmada vicdani zekâ ile vicdan algısı arasında pozitif yönlü, orta düzey bir ilişki tespit edilmiştir $(\mathrm{r}=, 527, \mathrm{p}<, 001)$. Ayrıca vicdani zekânın vicdan algısı üzerine etkisi istatistiksel olarak anlamlı $(\mathrm{p}<, 001)$ olduğu ve vicdani zekânın vicdan algısının \%28'sini açıkladığı bulunmuştur. Çalışmada sağlık çalışanlarında vicdani zekâ düzeyinin vicdan algısını olumlu yönde etkilediği sonucuna ulaşılmıştır.
\end{abstract}

Anahtar kelimeler: Vicdan, Vicdan Algisı, Vicdani Zekâ

\begin{abstract}
The purpose of the study is to evaluate the effect of conscientious intelligence on perception of conscience in healthcare professionals. The sample of the study consisted of 389 health workers serving in Turkey. In the research, a questionnaire consisting of scales whose validity and reliability was previously made was used. The scales was tested by Cronbach Alpha. SPSS Program was used to analyze the data. Relationship analysis was carried out by Pearson's correlation coefficient. ANOVA and t Tests were used for sociodemographic variables, and regression analysis was used for study impact analysis. In the study, no significant difference was found in terms of gender and educational status according to the averages of conscientious intelligence and perception of conscience. On the other hand, a significant difference was observed in terms of marital status and occupational groups. Again, according to the averages of conscientious intelligence and perception of conscience, age was determined to be an important determinant, and there are different studies in the literature. In the study, a positive, moderate relationship was found between conscientious intelligence and perception of conscience $(r=, 527, p$ $<, 001)$. In addition, where conscientious intelligence is significant $(\mathrm{p}<, 001)$ as its effect on perception of conscience, and conscientious intelligence explains $28 \%$ of the perception of conscience. In the study, it was concluded that the level of conscientious intelligence positively affected the perception of conscience among healthcare workers.
\end{abstract}

Keywords: Conscience, Perception of Conscience, Conscientious Intelligence

\footnotetext{
${ }^{1}$ Dr. Öğr Üyesi, Ali ARSLANOĞLU, Sağlık Yönetimi, Sağlık Bilimleri Üniversitesi, ali.arslanoglu@ sbu.edu.tr, ORCID:0000-0002-4454-0397

${ }^{2}$ Arş. Gör, Döne TÜTÜNCÜ, Sağlık Yönetimi, İstinye Üniversitesi, done.tutuncu@istinye.edu.tr, ORCID:0000-0002-4527-8968

${ }^{3}$ Doktora Öğr, Aylin Günay ATALI, Sağlık Yönetimi, Sağlık Bilimleri Üniversitesi, gunay.aylin@ gmail.com, ORCID:0000-0003-2238-0561

${ }^{4}$ Doç. Dr, Güven BEKTEMÜR, Sağlık Yönetimi, Sağlık Bilimleri Üniversitesi, guvenbek@gmail.com, ORCID: 0000-0001-5899-566X
} 


\section{GIIRIŞ}

İnsanı diğer canlılardan ayırt etmekteki en önemli özelliği hiç șüphesiz akıl sahibi olmasıdır. Kişi aklı ile iyi/kötü, doğru/yanlış, haklı/haksız ayrımını yapabilecek yetenektedir. Fakat insanlar sadece akli olarak davranışta bulunmazlar. Çoğu zaman vicdan, insanda aklın da ötesine geçen bir kontrol mekanizması olarak işlemektedir. Türk Dil Kurumu (TDK) Güncel Sözlük'te vicdan, "Kişiyi kendi davranışları hakkında bir yargıda bulunmaya iten, kissinin kendi ahlak değerleri üzerine dolaysiz ve kendiliğinden yargılama yapmasını sağlayan güç." olarak tanımlamaktadır. ${ }^{1}$ Diğer bir deyişle de vicdan, her insanın neyin doğru neyin yanlış olduğunu algılama ve bu algının gücüne dayanarak kontrol etme, izleme, değerlendirme ve yürütme yeteneğidir. ${ }^{2} \mathrm{Bu}$ tanımlar ışığında vicdanın insan hayatında büyük yer işgal ettiğini görmek mümkündür. Hem özel hem de iş hayatında kişinin davranışlarına yansımaktadır. Ayrıca meslek etiğinde de vicdan, temel yap1 taşı görevi görmektedir. ${ }^{3}$ Kişinin vicdan algısı duygu ve düşüncelerini yönlendirirken aynı zamanda bir stres yükü de taşımasına neden olabilmektedir. Özellikle sağlık çalışanları için bu yük çok daha hissedilir bir şekilde görülmektedir. ${ }^{4} \mathrm{Bu}$ sürecin başrol oyuncuları olan sağlık çalışanları aynı zamanda vicdani sorumluluk da baş başa kalmaktadır. Bu noktada çalışmada vicdani sorumluluklarının da arttığı bir süreci yaşayan sağlik çalışanlarının vicdani zekânın vicdan algısı üzerindeki etkisi değerlendirilmektedir.

\section{Covid-19 Pandemi Süreci}

Pandeminin Dünya Sağl1k Örgütünce de ifade edilen şekliyle en genel tanımı, "yeni bir hastalığın dünya çapında yayılması"dır.

Pandeminin etkisi virüsün yayılma hızına ve hastalı yapma yeteneğine, nüfusun bağışıklık yapısına, toplum insan ilişkilerinin düzeyine ve sağlık sistemlerine göre farklılık göstermektedir. Pandeminin şiddeti toplumun tamamı üzerinde etki yaratmaktadır. $\mathrm{Bu}$ etkiler başta sağlık olmak üzere ekonomik, kültürel ve sosyolojik olabilmektedir. Covid19 ile tanışan dünya toplumları bu etkileri
2020 y1lı başından itibaren derinden yaşamaktadır. Ülkeden ülkeye farklılık taşıyan etkiler söz konusu olsa da tüm insanlık hafızasına kazınacak bir sürece tanıklık edilmektedir.

Pandemi ile mücadele ederken karar vericiler, sağlik birimleri, ilgili kurum ve kuruluşlar koordineli bir şekilde çalışmaları gerekmektedir. $\mathrm{Bu}$ koordinasyonu iyi planlama ile yapmak mümkündür. Sürecin doğru planlanması etkili mücadeleyi de beraberinde getirmektedir. $\mathrm{Bu}$ bağlamda önceliklerin belirlenmesi, sağllk sisteminin cevap verme kabiliyetine göre bir yapılanmaya gidilmesi, gerekiyorsa ek tedbirlerin alınması, iş birliği-iletişim kanallarının açık tutulması ve süreç içinde etik kuralların göz ardı edilmemesi büyük önem taşımaktadır. Ülke yönetimleri ve sağlık sistemleri daha öncesinde tecrübe etmedikleri bir konuda sinav vermektedir. ${ }^{5}$ Ülkelerin Covid-19 sınavı hem yönetim hem sağlık sistemi hem de toplum için zorlu geçmektedir. $\mathrm{Bu}$ zorlukları en fazla yaşayanlardan sağlık çalışanları, bu sürecin en önemli aktörleridir. Pandeminin oluşturduğu stresle başa çıkabilmek diğer yandan da mesleklerinin gereğini yerine getirme durumunda olmaları oynadıkları rolü iki kat daha önemli ve zorlu kılmaktadır. Sağlık profesyoneli olmakla birlikte insan oldukları gerçeği atlanmadan, davranış ve eylemlerini değerlendirmek gerekmektedir. Pandemilerde hasta insanlarla yakın temasta olanlar sağlık çalışanları, ciddi risk altındadır. Bilhassa acil servis ve yoğun bakımlarda görevli sağlık çalışanlarının ruh sağlığı da önemli ölçüde etkilenmektedir. ${ }^{6}$

\section{Vicdan Algısı}

İnsanın aklının ötesinde bir kontrol mekanizması olan vicdan, kişinin davranış ve eylemlerinde ortaya çıkmaktadır. İnsan sahip olduğu algı düzeyi ile doğru orantılı olarak olayları, olguları, etrafinı ve insanları anlamlandırmaktadır. İnsanın farkındalığını ve ahlaki duruşunu şekillendiren vicdan algıs1, kişinin yaşam örgüsünü düzenlemektedir. 
Doğrudan ve birebir insanlarla temas halinde görevlerini ifa eden sağlık çalışanları için de vicdan, önemli bir mefhum olarak karşımıza çıkmaktadır. ${ }^{7}$ İşin muhteviyatı insan olduğunda salt mekanik yaklaşımla hareket edebilmesi mümkün değildir. Hem hastalar hem de hasta yakınları ile birebir çalışırken sağlık çalışanları mesleki etik ilkelerine, kişisel değerlerine ya da ahlaki duruşları ile çelişen bir durumda vicdanları ile karşı karşıya kalmaktadır. ${ }^{8}$ Sağlık hizmetlerinde ortaya çıkan günlük durumlar, sağlık çalışanlarının vicdanını etkileyen etik sorunları içermektedir. Vicdanın nasıl ve ne ölçüde etkilendiği, vicdanın nasıl algılandığına göre farklılık gösterebilmektedir.

Direkt olarak insana hizmet veren sağlik çalışanları etik değerleri ile çatışan bir durum yaşadığında vicdanın sesi ile karşı karşıya kalmaktadır. Bu uyarıcı ses, sürekli tekrar etmektedir. $\mathrm{Bu}$ ses nasıl algilanıp, değerlendirilirse o şekilde son bulmaktadır. Değerlendirme durumu umursama ya da umursamama şeklinde söz konusu olmaktadır. ${ }^{9}$ Her iki şekilde de sağlık çalışanı için vicdani bir yük oluşturmaktadır. Bu yük hem iş hayatını hem de özel hayatını olumsuz etkileyebilmektedir. Algilanan vicdani sorun çözülmediği takdirde de bu sürüp gitmektedir. $^{3}$

\section{Vicdani Zekâ}

Türkçe Sözlükte zekâ, insanın düşünme, akıl yürütme objektif gerçekleri algılama, yargılama ve sonuç çıkarma yeteneklerinin tamamı olarak tanımlanmaktadır. ${ }^{1}$ İnsanın öğrenme, öğrendiklerini muhakeme edebilme, muhakeme sonucunda yargiya varma ve bu yargilarına uygun hareket etme yeteneği olarak da ifade edilebilmektedir. ${ }^{10}$ En genel ifade ile zekâ, insanın çözüm bulma yetisidir. $\mathrm{Bu}$ doğrultuda vicdani zekâ da kişinin vicdani sorgulamaları ile hareket ederek sorunlara çözüm bulma kabiliyeti olarak tanımlanabilir. Vicdani zekâ, insanın iç sesine kulak vermesini sağlamakla birlikte hem kendine hem de etrafındakilere karşı mesuliyetlerini farkında olmasıdır. ${ }^{11}$ Kendi iç dinamikleri ile dış dünyayı algılayan insan, yine kendi vicdani süzgecinden geçirdiği doğrularla davranışlarını şekillendirmektedir. $\mathrm{Bu}$ şekillendirmenin temelinde dini inanışının gereği Allah'a karşı sorumluluk bilinci, akli hareket ederken ahlakı muhafaza etme, etik olanı göz ardı etmememe, bilgece davranma, alçak gönüllü olma, dürüstlüğü benimseme ve ilkeli davranma yer almaktadır. $^{12}$

\section{Değişkenler Arasındaki İlişki}

Sağlık hizmeti sunumunda temel öznesi insandır. Temelinde insan olan bu yapıy şekillendiren hasta-sağlık çalışanı ilişkisi kendi içinde pek çok değer taşımaktadır. Bu değerlerden vicdan, bu ilişkide önemli bir yer işgal etmektedir. Sağlık profesyonelleri tereddüt ettikleri bir durum ile karşı karşıya olduklarında vicdanlarının rehberliğine başvurmaktadırlar. ${ }^{13}$ Hareket ve davranışlarının temeline vicdanı alan kişilerin yürüttüğü faaliyetlerde tüm paydaşların da faydası gözlenmektedir. Böylelikle vicdanî zekâ kendiliğinden gelişen etik değerlerin kullanılmasını sağlamaktadır. ${ }^{14}$

Vicdani zekânın daha önce Arslanoğlu ve Tabur'un (2019) yaptığı çalışmada hasta beklentilerini yönetme becerilerini etkilediğini ortaya konmuştur. İnsanı tanıma ile ilgili psikometrik özellikli bu ölçeği kullanarak vicdan algısı üzerinde etkilerini irdelenmeye çalışılmıştır. ${ }^{13}$ Urgan (2020) yaptığı çalışmada vicdanî zekâ düzeyinin iş performansını ve aynı şekilde yaşam memnuniyetini de artıracağını vurgulamıştır. Vicdani zekânın bir başka yönü de sağlık çalışanlarının zorlu çalışma koşullarına manevi değer atfederek katlanılır kılmaktadır. ${ }^{14}$ Profesyonel çalışma sahasının manevi değerleri ile birleştirmek bireyin kişisel ahlaki ve mesleki etik değerlerinin de ötesinde yer almaktadır. ${ }^{15}$ Vicdani zekâ düzeyinin çalışanlarının iş performansını da olumlu yönde etkilediği ortaya konulmuştur. ${ }^{16}$

Sağlık çalışanlarının vicdanı nasıl algıladıklarının vicdan stresi ile ilişkili olduğu gösterilmiştir. ${ }^{17}$ Başka bir çalışmada kişinin vicdanını bir yük olarak algılamanın, duygusal tükenme ve duyarsızlaşma duygularına sahip olmanın ve çalışanlar 
arasında rahatsız edici çatışmaları fark etmenin vicdan stresi ile pozitif ilişkili olduğu tespit edilmiştir. Vicdan stresinin etkilerini durdurmak için, işinde vicdanını takip etmek, ifade etmek ve üstlerinden sosyal destek almak önemlidir görüşü vurgulanmıştır. ${ }^{18}$

Sağlık çalışanlarının stres, tükenmişlik ve etik zorluklar ilgili deneyimler, vicdanlarını rahatsız etmektedir. Vicdanı bir yük değil, bir varlık olarak görmektedirler. ${ }^{19} \mathrm{Bu}$ bağlamda vicdanı bastırmak, bütünlük ve uyum kaybına neden olabilmektedir. ${ }^{20}$ Glasberg ve diğerleri (2008) yaptıkları çalı̧̧mada işyerinde kişinin vicdanını takip edememesi ve ahlaki sorunlarla başa çıkamama olan ahlaki duyarlılı̆ğn "olumsuz" boyutu ahlaki yük buna katkıda bulunan özel faktörler olarak değerlendirilmiştir. ${ }^{21}$ Dolayısıyla vicdan ve ahlaki duyarlılığın bir yük olmaktan çıkıp bir varlık haline gelebilmesi için sağlık çalışanlarının ahlaki kaygılarını ifade edebilmeleri gerektiği ortaya konulmuştur. Bu ahlaki kaygıyı vicdani zekâ ile ilişsilendirmek de mümkündür. Vicdani zekâ olarak tanımlanan kavram büyük ölçüde kişinin taşıdığ 1 ahlaki duyarlılığı da içine almaktadır. Bu duyarlılık ve algıyla sağlık çalışanları daha dingin şekilde çalışmaktadır. Vicdani zekânın kişiye en büyük faydası iç huzurdur. ${ }^{11}$

\section{MATERYAL VE METOT}

\section{Araştırmanın Tipi ve Zamanı}

Araştırma kesitsel ve tanımlayıcı tiptedir. Araştırma 16.01.2021-15.02.2021 tarihler arasında yapılmıştır.

\section{Araştırmanın Evren ve Örneklemi}

Araştırmanın evreni, Türkiye'de görev yapan sağlık çalışanlarıdır. Çalışmada basit tesadüfi örnekleme yöntemi kullanılmıştır ve örneklem büyüklüğü 389'dur. Sekaran'a göre, 100.000 ve üzeri evren büyüklükleri için 384 örneklem büyüklüğü yeterlidir. ${ }^{22}$ Araştırmaya 18 yaş ve üzeri olan sağlık çalışanları dâhil edilmiştir. 18 yaş altı ve sağlık çalışanı olmayanlar araştırma kapsamı dişında tutulmuştur. Çalışmada veriler Google Forms da hazırlanarak online olarak toplanmıştır. Toplanan anketlerden eksik ya da yanlış doldurulanlar çalışmaya dâhil edilmemiştir. Toplam 390 anket toplanmasına rağmen, 1 tane anket yarıda bırakıldığı için çalışmaya dâhil edilmemiştir.

\section{Verilerin Analizi}

Araştırma verileri ilk olarak Excel Programında toplanmış, gerekli dönüştürme, düzeltme işlemleri gerçekleştirildikten sonra SPSS Programına aktarılmıştır. Verilerin analizi SPSS Programı kullanılarak gerçekleştirilmiştir. Kategorik değişkenler frekans ve yüzdelerle tanımlanmıştır. Ölçeklerin güvenirliği Cronbach Alpha
Yöntemi ile test edilmiş ve $\alpha>0.70$ bulunması halinde çalışma devam edilmiştir. Veriler normal dağılıma uygunluk gösterdiği için Pearson korelasyon katsayısı yardımı ile ilişki analizleri gerçekleştirilmiştir. ANOVA Testleri ve $t$ Testi ile sosyodemografik değişkenlerin farklılıkları tespit edilmiştir. Sosyodemografik değișkenler için farklılık testlerinden $\mathrm{t}$ Testi ve ANOVA Testleri kullanılmıştır. Regresyon analizi araştırmada verilerin etki analizinde kullanılmıştır.

\section{Veri Toplama Araçları}

Araştırmada daha önceden geçerlilik ve güvenilirliği yapılan ölçekler kullanılarak, verilerin toplanmasında çevrim içi anket formu kullanılmıştır. Araştırma, tanıtım yazısı ve üç bölümden oluşmaktadır. İlk bölümde katılımcıların sosyodemografik özelliklerini kapsayan 5 soru yer almaktadır. İkincisinde vicdan algisına dair 13 maddelik ölçek ve üçüncü bölümde vicdani zekâya dair 32 maddelik ölçek yer almaktadır. "Kişisel Bilgi Formu", "Vicdan Algısı Ölçeği", ve "Vicdani Zekâ Ölçeği" başlığı altında araştırma verileri toplanmıştır.

\section{Kişisel Bilgi Formu}

Araştırmacıların hazırladığı katılımcıların sosyodemografik (yaş, cinsiyet, medeni durum, meslek, öğrenim durumu) bilgilerinin yer aldığı, formdur. 


\section{Vicdan Algısı Ölçeği}

2007 yılında Dahlqvist ve arkadaşlarının geliştirilen ölçek, Aksoy ve arkadaşları tarafindan 2019 y1lında Türkçe'ye çevrilmiştir. Ölçekteki sorular 6'l likert tarzında; "Hayır, tamamen katılmıyorum" (1 puan); "Evet, tamamen katıliyorum" (6 puan) olarak puanlandırılmaktadır. Ölçekte toplam 13 madde yer almaktadır. Ölçek iki faktörden oluşmaktadır. Faktör 1 Duyarlılık (Madde 1, 2, 3, 4, 5, 6, 7, 8, 10, 12, 13), Faktör 2 Otorite (Madde 9, 11) şeklindedir. Aksoy ve arkadaşları ölçeğin Cronbach Alpha katsayısını 0,84 olarak bulmuştur. $\mathrm{Bu}$ çalışmada ölçeğin Cronbach Alpha katsayısı, 0,88 olarak tespit edilmiştir.

\section{Vicdani Zekâ Ölçeği}

2017 yılında Aktı ve arkadaşları tarafından geliştirilmiştir. Ölçek 32 maddeden ve 7 alt faktörden oluşmaktadır. $\mathrm{Bu}$ alt faktörler Etik Değerler, Ahlâki Duyarlılık, Yaratıcıya Karşı Sorumluluk, Merhamet, Bilinçli Farkındalık, Toplumsal Duyarlılık ve Bilgelik. Ölçekteki sorular 5'li likert tarzında oluşturulmuştur. "1. Hiç Katılmiyorum", "2. Katılmiyorum", "3. Kararsızım”, “4. Katıliyorum”, "5. Tamamen Katılıyorum" şeklinde cevaplanmaktadır. Alınabilecek en yüksek puan 160 ve en düşük puan 32dir. 1., 2., 3., 4. ve 5. sorular ölçekte tersten kodlanmıştır. Aktı ve arkadaşları ölçeğin Cronbach Alpha katsayısını 0,85 olarak bulmuştur. $\mathrm{Bu}$ çalışmada ölçeğin Cronbach Alpha katsayısı 0,91 olarak bulunmuştur.

\section{Araştırmanın Soruları}

Araştırma soruları aşağıda verilmektedir.

- Vicdani zekâ ile vicdan algısı arasında anlamlı bir ilişki var mıdır?

- Vicdani zekâ vicdan algısını pozitif yönde etkiler mi?

\section{Araştırmanın Sınırlılıkları}

Verilerin anlık olarak toplanması ve zaman içinde değişimin de belirlenebilmesi için değişik zamanlarda araştırmanın yap1lamamas1 ve online olarak toplanmas1 araştırmanın sinırlılıkları olarak görülmektedir.

\section{Araştırmanın Etik Yönü}

Çalışmanın etik kurul izni, İstanbul Sağlık Bilimleri Üniversitesi, Hamidiye Bilimsel Araştırmalar Etik Kurulu'ndan 15.01.2021 tarih ve 2730 sayılı etik kurul kararı ile alınmıştır. Çalışmada kullanılan ölçekler için araştırmacılardan izin alınmıştır. Ayrıca araştırmaya katılanlardan ankete başlamadan önce gönüllü onam alınmıştır.

\section{BULGULAR VE TARTIŞMA}

Çalışma kapsamında araştırmaya katılanların cinsiyeti, medeni durumu, yaşı, öğrenim durumu, mesleğine ilişkin veriler incelenmiş, değişkenlere ait sıklık (frekans) ve yüzde değerleri sunulmuştur. Katılımcıların Tablo 1'de görüldügüü üzere; cinsiyetlerine bakıldığında \%68,6's1 kadın, \%31,4'ü erkektir. Medeni durumlarına bakıldığında; \%59,9'unun evli, yaşlarına bakıldığında \%20,6'sının 41-45 yaş arasında olduğu görülmektedir. Öğrenim durumlarına bakıldığında; \%46'sının lisansüstü mezunu olduğu; meslek olarak bakıldığında \%45'inin hemşire olduğu görülmektedir. 
Tablo 1. Sosyo-demografik Özelliklere İlişkin Bulgular

\begin{tabular}{|c|c|c|c|}
\hline Değişkenler & & $\mathbf{n}$ & $\%$ \\
\hline \multirow{3}{*}{ Cinsiyet } & Kadın & 267 & 68,6 \\
\hline & Erkek & 122 & 31,4 \\
\hline & Toplam & 389 & 100 \\
\hline \multirow{3}{*}{ Medeni Durum } & Evli & 233 & 59,9 \\
\hline & Bekâr & 156 & 40,1 \\
\hline & Toplam & 389 & 100 \\
\hline \multirow{7}{*}{ Yaş } & 25 ve alt 1 & 53 & 13,6 \\
\hline & $26-30$ & 77 & 19,8 \\
\hline & $31-35$ & 52 & 13,4 \\
\hline & $36-40$ & 64 & 16,5 \\
\hline & $41-45$ & 80 & 20,6 \\
\hline & 46 ve üzeri & 63 & 16,2 \\
\hline & Toplam & 389 & 100 \\
\hline \multirow{5}{*}{$\begin{array}{l}\text { Öğrenim } \\
\text { Durumu }\end{array}$} & Lise & 16 & 4,1 \\
\hline & Önlisans & 31 & 8,0 \\
\hline & Lisans & 163 & 41,9 \\
\hline & Lisansüstü & 179 & 46,0 \\
\hline & Toplam & 389 & 100 \\
\hline \multirow{6}{*}{ Meslek } & Doktor & 107 & 27,5 \\
\hline & Hemşire & 175 & 45,0 \\
\hline & Ebe & 35 & 9,0 \\
\hline & Tekniker/teknisyen & 31 & 8,0 \\
\hline & Diğer & 41 & 10,5 \\
\hline & Toplam & 389 & 100 \\
\hline
\end{tabular}

n: kişi sayısı, \%: kişi sayısının yüzdesel ifadesi

Tablo 2. Ölçek Ortalamalarının Demografik Değişkenlere Göre Farklılaşma Durumu

\begin{tabular}{|c|c|c|c|c|c|}
\hline Ölçekler & Değişkenler & $\bar{x}$ & Ss & $\mathbf{t}$ & $\mathbf{p}$ \\
\hline \multirow{3}{*}{$\begin{array}{l}\text { Vicdan Algısı } \\
\text { Ölçeği }\end{array}$} & Cinsiyet & & & \multirow{3}{*}{,778 } & \multirow{3}{*}{, 437 } \\
\hline & Kadın & 4,88 & ,82 & & \\
\hline & Erkek & 4,81 &, 90 & & \\
\hline \multirow{3}{*}{$\begin{array}{l}\text { Vicdani Zekâ } \\
\text { Ölçeği }\end{array}$} & Kadın & 4,23 & ,40 & \multirow[t]{2}{*}{,- 785} & \multirow[t]{2}{*}{,433 } \\
\hline & Erkek & 4,26 &, 40 & & \\
\hline & \multicolumn{3}{|c|}{ Medeni Durum } & & \\
\hline Vicdan Algısı & Evli & 4,98 & ,79 & 3,243 &, $001 *$ \\
\hline Ölçeği & Bekâr & 4,69 &, 89 & & \\
\hline Vicdani Zekâ & Evli & 4,31 &, 39 & 4,354 &, $000 * *$ \\
\hline Ölçeği & Bekâr & 4,13 & 39 & & \\
\hline
\end{tabular}

Tablo 2 incelendiğinde yapılan $t$ Testi sonucuna göre, medeni durum değişkeni açısından vicdan algısı ölçek ortalaması arasında anlamlı bir fark olduğu $(p=, 001)$ tespit edilmiştir. Benzer bir biçimde medeni durum değişkeni açısından vicdani zekâ ölçek ortalaması arasında anlamlı bir fark olduğu $(\mathrm{p}=, 000)$ görülmüştür
Tablo 2'ye göre cinsiyet değişkeni açısından katılımcıların, ölçek ortalamaları ile arasında istatistiksel olarak anlamlı bir fark olmadığ 1 tespit edilmiştir.

Tablo 3 incelendiğinde yapılan ANOVA Testi sonucuna göre, yaş değişkeni açısından vicdan algısı ölçek ortalamaları arasında anlamlı bir fark $(p=, 000)$ olduğu ortaya çıkmıştır. $\mathrm{Bu}$ farkın hangi gruptan kaynaklandığını saptamak için Post-Hoc Analizi yapılmıştır. $\mathrm{Bu}$ analiz sonucunda, Vicdan Algısı Ölçeği'nde 25 ve altı grubun; 36-40, 46 ve üzeri yaş grupla farklılaştığı ve daha düşük vicdan algısı puanına sahip olduğu tespit edilmiştir. Benzer şekilde 26-30 yaş arası grubun; 36-40, 46 ve üzeri yaş grupla farklılaştığ algısı puanına sahip olduğu saptanmıştır. Diğer bir bulgu 31-35 yaş aralığındaki grubun; 36-40, 41-45, 46 ve üzeri yaş aralığındaki gruplara göre farklılaştığı ve daha düşük vicdan algısı puanına sahip olduğu tespit edilmiştir. Yaş arttıkça vicdan alg1sı yükselmektedir.

Yine Tablo 3'e göre, yaş değişkeni açısından vicdani zekâ ölçek ortalaması arasında anlaml bir fark $(p=, 003)$ bulunmuştur. $\mathrm{Bu}$ farkın saptamak için yapilan Post-Hoc Analizi sonucunda, 26-30 yaş aralığındaki grubun 36-40, 46 ve üzeri gruba göre farkl1laştığ 1 ve daha düşük vicdani zekâ puanına sahip olduğu görülmüştür. Yaş arttıkça vicdani zekâ yükselmektedir. 
Tablo 3. Ölçek Ortalamalarının Demografik Değişkenlere Göre Farklılaşma Durumu

\begin{tabular}{|c|c|c|c|c|c|c|c|c|}
\hline Ölçekler & Değişkenler & $\bar{x}$ & Ss & Min. & Max. & $\mathbf{F}$ & $\mathbf{p}$ & Post-hoc \\
\hline & \multicolumn{8}{|c|}{ Yaș } \\
\hline & 25 ve alt1(a) & 4,59 & ,70 & 2 & 6 & & & \\
\hline & $26-30(\mathrm{~b})$ & 4,66 & ,92 & 2 & 6 & & & $\mathrm{a}<\mathrm{d}, \mathrm{f}$ \\
\hline Vicdan & $31-35(c)$ & 4,57 & 92 & 1 & 5 & 6,474 &, $000 *$ & $\mathrm{~b}<\mathrm{d}, \mathrm{f}$ \\
\hline Algisı & $36-40(d)$ & 5,08 &, 77 & 2 & 6 & & & $\mathrm{c}<\mathrm{d}, \mathrm{e}, \mathrm{f}$ \\
\hline \multirow[t]{4}{*}{ Ölçeği } & $41-45(e)$ & 5,00 &, 82 & 1 & 6 & & & \\
\hline & 46 ve üzeri(f) & 5,17 &, 70 & 2 & 6 & & & \\
\hline & 25 ve alt1(a) & 4,17 & ,39 & 2 & 4 & & & \\
\hline & $26-30(\mathrm{~b})$ & 4,12 &, 40 & 3 & 4 & & & \\
\hline Vicdani & $31-35(c)$ & 4,17 & 49 & 2 & 5 & 3,732 &, $003 *$ & $\mathrm{~b}<\mathrm{d}, \mathrm{f}$ \\
\hline Zekâ & $36-40(d)$ & 4,32 &, 39 & 3 & 5 & & & \\
\hline \multirow[t]{2}{*}{ Ölçeği } & $41-45(\mathrm{e})$ & 4,30 &, 38 & 3 & 4 & & & \\
\hline & 46 ve üzeri(f) & 4,34 &, 35 & 3 & 5 & & & \\
\hline \multirow{5}{*}{$\begin{array}{l}\text { Vicdan } \\
\text { Algısı } \\
\text { Ölçeği }\end{array}$} & \multicolumn{8}{|c|}{ Öğrenim Durumu } \\
\hline & Lise & 4,72 & 1,04 & 2 & 6 & \multirow{4}{*}{1,853} & \multirow{4}{*}{, 137} & \\
\hline & Önlisans & 5,11 & ,64 & 3 & 6 & & & \\
\hline & Lisans & 4,77 & 85 & 1 & 6 & & & \\
\hline & Lisansüstü & 4,91 &, 84 & 1 & 6 & & & \\
\hline \multirow{4}{*}{$\begin{array}{l}\text { Vicdani } \\
\text { Zekâ } \\
\text { Ölçeği }\end{array}$} & Lise & 4,13 &, 51 & 2 & 4 & \multirow{4}{*}{1,000} & \multirow{4}{*}{,393 } & \\
\hline & Önlisans & 4,16 &, 44 & 2 & 5 & & & \\
\hline & Lisans & 4,24 & ,36 & 3 & 5 & & & \\
\hline & Lisansüstü & 4,26 &, 42 & 3 & 5 & & & \\
\hline \multirow{6}{*}{$\begin{array}{l}\text { Vicdan } \\
\text { Algısı } \\
\text { Ölçeği }\end{array}$} & \multicolumn{8}{|c|}{ Meslek } \\
\hline & Doktor(a) & 4,61 & ,92 & 1 & 6 & \multirow{5}{*}{4,598} & \multirow{5}{*}{, $001 *$} & \multirow{5}{*}{$\mathrm{a}<\mathrm{b}, \mathrm{c}$} \\
\hline & Hemşire(b) & 4,98 &, 72 & 2 & 6 & & & \\
\hline & $\operatorname{Ebe}(\mathrm{c})$ & 5,10 &, 72 & 3 & 6 & & & \\
\hline & Tekniker/teknisyen(d) & 4,96 & 87 & 2 & 6 & & & \\
\hline & Diğer (e) & 4,71 & 1,03 & 1 & 6 & & & \\
\hline \multirow{5}{*}{$\begin{array}{l}\text { Vicdani } \\
\text { Zekâ } \\
\text { Ölçeği }\end{array}$} & Doktor(a) & 4,10 & ,44 & 2 & 4 & \multirow{5}{*}{5,227} & \multirow{5}{*}{, $000 *$} & \multirow{5}{*}{$\mathrm{a}<\mathrm{b}, \mathrm{c}, \mathrm{d}$} \\
\hline & Hemşire(b) & 4,26 &, 37 & 2 & 5 & & & \\
\hline & $\operatorname{Ebe}(\mathrm{c})$ & 4,37 &, 35 & 3 & 5 & & & \\
\hline & Tekniker/teknisyen(d) & 4,35 &, 39 & 3 & 5 & & & \\
\hline & Diğer(e) & 4,29 &, 40 & 3 & 5 & & & \\
\hline
\end{tabular}

Tablo 3'e göre, meslek değişkeni açısından vicdan algisı ölçek ortalaması arasında anlamlı bir fark $(\mathrm{p}=, 001)$ olduğu bulunmuştur. $\mathrm{Bu}$ farkın hangi gruptan kaynaklandığını saptamak için yapılan PostHoc Analizi sonucunda, doktorların vicdan algısı puanlarının hemşire ve ebelerden farklı ve düşük olduğu bulunmuştur.

Tablo 3 incelendiğinde meslek değişkeni açısından vicdani zekâ ölçek ortalaması arasında anlamlı bir fark $(p=, 000)$ saptanmıştır. Söz konusu farkın hangi gruptan kaynaklandığını saptamak için yapilan Post-Hoc Analizi sonucunda, doktorların vicdani zekâ puanlarının hemşire, ebe ve tekniker/teknisyene göre farklı ve düşük olduğu tespit edilmiştir.

Tablo 3 incelendiğinde ANOVA Testi sonucuna göre, öğrenim durumu açısından ölçek ortalamaları ile arasında istatistiksel olarak anlamlı bir fark olmadığ görülmüştür.
Tablo 4. Ölçek Ortalamalarına Göre Korelasyon Analizi Değerleri

\begin{tabular}{lll}
\hline Değişken & Vicdani Algı Ölçeği & Vicdani Zekâ Ölçeği \\
$\begin{array}{l}\text { Vicdan algısı } \\
\text { ölçeği }\end{array}$ & 1 & \\
$\begin{array}{l}\text { Vicdani zekâ } \\
\text { ölçeği }\end{array}$ &, $\mathbf{5 2 7}$ & 1 \\
\hline *p<0,001 & &
\end{tabular}

Tablo 4'e göre, vicdani zekâ ile vicdan algısı arasında pozitif yönlü, orta düzey bir ilişkinin var olduğu tespit edilmiştir. $(\mathrm{r}=, 527, \mathrm{p}<, 001)$. Vicdani zekâ ile vicdan algısı arasında anlamlı bir ilişki bulunmuştur.

Tablo 5'te vicdani zekânın vicdan algısının yaklaşık \%28'sini açıkladığı görülmektedir. Vicdani zekânın vicdan alg1s1 üzerine etkisi istatistiksel olarak anlamlı $(\mathrm{p}<, 001)$ bulunmuştur. Vicdani zekânın vicdan algısını pozitif yönde etkilediği bulunmuştur. 
Tablo 5. Ölçek Ortalamalarına Göre Regresyon Analizi Sonuçları

\begin{tabular}{|c|c|c|c|c|c|}
\hline \multirow[t]{2}{*}{ Değişken } & \multicolumn{2}{|c|}{$\begin{array}{l}\text { Standardize } \\
\text { Edilmemiş } \\
\text { Katsayı }\end{array}$} & $\begin{array}{l}\text { Standardize } \\
\text { Katsayı }\end{array}$ & \multirow[t]{2}{*}{$\mathbf{t}$} & \multirow[t]{2}{*}{$\mathbf{p}$} \\
\hline & B & $\begin{array}{r}\text { Std. } \\
\text { Hata }\end{array}$ & Beta & & \\
\hline Sabit & 0,219 & 0,382 & & 0,574 & 0,566 \\
\hline $\begin{array}{l}\text { Vicdani } \\
\text { Zekâ }\end{array}$ & 1,095 & 0,090 & 0,527 & 12,206 & $0,000 *$ \\
\hline \multicolumn{6}{|c|}{ Bağımlı değişken: Vicdan Algısı } \\
\hline $\begin{array}{l}F=148,975 \\
N=389, R= \\
\text { Durbin } W a\end{array}$ & $\begin{array}{l}\mathrm{p}=0,000 \\
527, \mathrm{R}^{2}= \\
\text { son }=1,9\end{array}$ & $\begin{array}{l}278 \\
3 \\
\end{array}$ & & & \\
\hline
\end{tabular}

389 kişiye yapılan bu çalışmanın sonucunda, sağlık çalışanlarının vicdani zekâları ile vicdan algıları arasında anlamlı bir ilişki olduğu bulunmuştur. Yine çalışmada bazı demografik özellikler açısından vicdani zekâ ile vicdan algısı arasında farklılıklar bulunmuştur.

Çalışmada vicdani zekâ ortalamalarına göre cinsiyet açısından anlamlı bir fark bulunmamıştır. Glasberg'in (2007) sağlı çalışanları üzerinde yaptığı bir araştırmada, kadın sağlık çalışanlarının erkek sağlık çalışanlarına göre vicdanlarına daha sık başvurdukları ve vicdana dayanan nedenler ile daha yüksek oranda duygusal tükenme yaşadıklarını saptaması bu çalışma ile farklılık göstermektedir. ${ }^{23}$ Alpullu ve arkadaşları (2010), Sonmaz (2002), Çoban ve arkadaşları (2010), Gujjar ve arkadaşları (2010), Adiloğulları (2011), Arslanoğlu ve Tabur (2019), Şengül ve Bulut (2020) tarafından ele alınan çalışmalarda vicdani zekânın cinsiyete göre farklılaşmadığ 1 bulunmuştur. ${ }^{13,15,24-27} \mathrm{Bu}$ sonuçlar bizim çalışmamız ile benzerlik göstermektedir.

Çalışmada medeni durum açısından vicdani zekâ ortalamaları arasında anlamlı bir fark bulunmuştur. Bekâr bireylere göre evli bireylerin vicdani zekâ ortalamaları daha yüksek düzeyde olduğu saptanmıştır. $\mathrm{Bu}$ çalışma ile benzerlik gösteren, vicdanî zekâ ile ilişkili olduğu düşünülen ruhsal zekâ ile yapılmış olan çalışmada; evli olan ve evli olmayan kadınlar arasında anlamlı bir fark ortaya konulmuştur. ${ }^{29}$ Çalışma ile farklılık gösteren çalışmalarda mevcuttur. Arslanoğlu ve Tabur tarafindan (2019) yapılan çalışmada, vicdani zekâ ve medeni durum arasında anlamlı bir fark olmadığı sonucuna varılmıştır. ${ }^{13}$ Sonuç olarak evli olan bireylerin sorumluluklarının artmasına bağlı olarak vicdani zekâ puanları da artış göstermektedir. Pandemi döneminin de bu farkta etkisinin olabileceği düşünülmektedir.

Katılımcıların yaş gruplarında vicdani zekâ ortalamaları arasında anlamlı bir fark görülmüştür. Çalışmada yaşın ilerlemesi ile vicdani zekânın arttığı görülmüştür. Çoban ve arkadaşlarının (2010) yaptığı çalışmada da yaş ilerledikçe vicdani zekâ puanları arttığ1 belirtilmiştir. Çalışmada yaş alan kişilerin olgunlaşmasıyla birlikte olaylara daha realist yaklaştıkları ve hayatın gereklerine daha rahat adapte olmaları ile ifade edilebileceğini belirtmektedirler. ${ }^{24} \mathrm{Bu}$ durum yaptığımız çalışmayı destekler niteliktedir. Arslanoğlu ve Tabur (2019), Şengül ve Bulut (2020) tarafından ele alınan çalışmalarda vicdani zekâ ve yaş grubu arasında anlamlı bir bulunmaması yapılan çalışma ile farklılık göstermektedir. ${ }^{13,15} \mathrm{Bu}$ çalışma sonucunda yaş ilerledikçe vicdani zekanın arttığı görülmektedir. Bunun nedeni insanların yaşı artıkça olgunlaşması, hayata bakış açılarının değişmesi ve sorumluluklarının artması olarak düşünülmektedir.

Çalışmada öğrenim durumu açısından vicdani zekâ ortalamaları arasında farklılık göstermediği bulunmuştur. Benzer şekilde Arslanoğlu ve Tabur tarafindan (2019) yapılan çalışmada vicdani zekâ ortalamalarının öğrenim durumu açısından anlamlı bir fark olmadığ tespit edilmiştir. ${ }^{13}$ Sağlık çalışanları üzerine yapılan iki çalışmada da vicdani zekânın öğrenim durumuna göre değişmediği bulunmuştur.

Meslek grupları açısından bakıldığında vicdani zekâ ortalamaları arasında anlamlı bir fark olduğu tespit edilmiştir. Çalışmada doktorların vicdani zekâ puanlarının hemşire, ebe ve tekniker/teknisyene göre düşük olduğu tespit edilmiştir. Arslanoğlu ve Tabur tarafindan (2019) ele alınan çalışmada meslek grupları arasında vicdani zekâ açısından anlamlı bir fark bulunmamıştır. Yapılan tespit bu çalışma ile farklılık taşımaktadır. Bu durum özellikle 
pandemi döneminde hastalar ile daha çok temas eden meslek gruplarının vicdani zekâ puanlarının daha yüksek olması ile açıklanabilir.

Çalışmada vicdan algısı puanının cinsiyet açısından farklılık göstermediği bulunmuştur. $\mathrm{Bu}$ durum sağlık çalışanlarının vicdanı nasıl algıladığ ile ilgilidir. Dahlgvist ve arkadaşları (2007) yapmış oldukları çalışmada kişiler vicdanı ahlaki ve sosyal değerleri, hayata bakış açısına göre algılayabilir. Çalışanlara göre vicdanın ana işlevinin "kendilerini ve diğerlerini incitmekten korumakta olan bir otorite" olarak algılandığını ifade etmişlerdir. ${ }^{7}$ Ahlin ve arkadaşları (2015) yapmış oldukları çalışmada "sağlık çalışanlarının vicdanı bir yük olarak algıladığını ve sağlık kuruluşlarında çalışabilmek için vicdanlarını öldürmek zorunda kaldıklarını" ifade etmişlerdir. ${ }^{18} \mathrm{Bu}$ çalışmalara göre vicdanın algılanma şeklinin cinsiyete göre değil çalışanların tutum, inanç ve değerlerine göre farklılaştığı yorumu yapılabilir.

Çalışmada katılımcıların yaş gruplarında vicdan algısı puanı açısından anlamlı bir farklılık bulunmuştur. Yaş ilerledikçe vicdan algısı puanları artmaktadır. Çoban ve arkadaşları (2010) yaşın ilerlemesiyle birlikte bireylerin vicdani olgunluk sürecine girmeleri ve olaylara daha gerçekçi yaklaşıp yaşamın gereklerine daha başarılı uyum sağlamaları ile açıklanabileceğini ifade etmektedirler. $^{26} \mathrm{Bu}$ durum çalışmayı destekler niteliktedir. Bu durum bireylerin olgunlaşmaları, hayatın gerekliliklerini anlamaları sonucunda vicdan algılarının artması ile açıklanabilir. Juthberg ve arkadaşları (2010) tarafından ele alınan çalışmada yaş grupları arasında bir fark olmadığı sonucuna ulaşılması bu çalışma ile farkl1lık göstermektedir. ${ }^{19}$

Çalışmada vicdan algısı puanının medeni durum açısından farklılık gösterdiği bulunmuştur. Evli olan sağlık çalışanlarının bekâr olanlara göre vicdan algıları daha yüksek çıkmıştır. Bunun nedeni evli bireylerin sorumluluklarının artması ile yorumlanabilir.

Meslek grupları açısından bakıldığında vicdan algisı ile anlamlı bir fark olduğu tespit edilmiştir. Çalışmada doktorların vicdan algısı puanlarının hemşire ve ebelere göre düşük olduğu bulunmuştur. Juthberg ve arkadaşları tarafından ele alınan (2010) çalışmada bir fark olmadığı sonucuna ulaşması bu çalışma ile farklılık göstermektedir. ${ }^{19}$ Çalışma sonucunda hasta ile daha çok temas eden ve onun bakımını sağlayan meslek grubunda vicdan algis1 daha yüksektir. Hastanın tedavi ve bakım sırasında ortaya çıkan olumsuzluklara daha çok şahit olan mesleklerin vicdan algısının daha yüksek olduğu düşünülmektedir.

Pandemi sürecinde yapılan bu çalışmada vicdani zekâ ile vicdan algısı arasında pozitif yönlü, anlamlı ve orta düzeyde bir ilişki tespit edilmiştir. Bazı çalışmalar ise vicdan algisının vicdan stresi ve tükenmişlikle ilişkili olduğunu ortaya koymuştur. ${ }^{17-19,21}$ Çalışmayı planlarken vicdani zekâ düzeyi ile vicdan algısı arasında anlamlı ve pozitif yönde bir ilişki tahmin ediliyordu. Öncesinde oluşturulan araştırma soruları çalışma sonunda cevaplanmıştır. Sağlık çalışanlarının vicdani zekâ düzeyleri arttıkça vicdani algı düzeyleri de artmaktadır.

Çalışmada vicdani zekânın vicdan algısını pozitif yönde etkilediği bulunmuştur. Farklı çalışmalarda vicdani zekâ ile iş performansı arasında pozitif yönlü bir ilişki olduğunu ortaya konmuştur. ${ }^{14,16}$ Vicdani zekâ ile ilişsili olan ruhsal zekânın iş memnuniyetini ve örgütsel bağlılığı olumlu yönde etkilediğini ortaya koyan çalışmalar bulunmaktadır. ${ }^{30-33}$ Ruhsal zekânın liderlik üzerinde etkili olduğunu ortaya koyan çalışmalar da bulunmaktadır. ${ }^{34,35}$ Arslanoğlu ve Tabur (2019) ise vicdani zekânın hasta beklentilerini yönetme becerisi üzerine etkisini ortaya koymuşlardır. ${ }^{13}$ 


\section{SONUÇ VE ÖNERILLER}

Covid-19 pandemi sürecinde gerçekleştirilen çalışmada sağlık çalışanlarının vicdani zekâ düzeylerinin vicdani algılarını etkilediği görülmektedir. Araştırmada sağlık çalışanlarında vicdani zekâ ve vicdan algısı bazı sosyodemografik özelliklerin bazılarına göre farklılık gösterirken, bazı özelliklere göre farklılık göstermediği saptanmıştır. Pandemi sürecinde sağlık çalışanları, vicdanı kendilerine yol gösteren bir rehber olarak gördükleri ifade edilebilir. Vicdanları sayesinde hem kendileri hem hastaları için yanlış yapmaktan sakınan tutum geliştirme yönünde gayret içindedirler. Yaşadıkları vicdani hassasiyet mesleki etik ilkeleri ile de paralellik göstermektedir.

Vicdani zekâ literatüre yeni bir kavram olarak girmiştir. Bu konuda farklı alanlarda ve farklı örneklem gruplarıla yeni çalışmalar planlanabilir. 


\section{KAYNAKLAR}

1. TDK (2011). Büyük Türkçe Sözlük. Ankara: Türk Dil Kurumu Yayınları.

2. Vithoulkas, G. and Muresanu, D. (2014). "Conscience and Consciousness: A Definition". Journal of Medicine and Life, 7 (1), 104-108.

3. Aksoy, S. Mert, K. ve Çetin, İ. (2019). "Vicdan Algıs Ölçeği'nin Türkçe Geçerlilik Güvenilirliği’”. Celal Bayar Üniversitesi Sağlık Bilimleri Enstitüsü Dergisi, 6 (3), 148-153

4. Jokwiro, Y, Pascoe, E, Edvardsson, K, Rahman, M.A McDonald, E, Lood, Q. and Edvardsson, D. (2020). "Stress of Conscience Questionnaire (SCQ): Exploring Dimensionality and Psychometric Properties at A Tertiary Hospital İn Australia”. BMC Psychol. 8, 109.

5. Crosby, A.W. (2003). America's Forgotten Pandemic: The Influenza of 1918. United States of America: Cambridge University Press.

6. Bozkurt, Y, Zeybek, Z. ve Aşkın, R. (2019). "Covid-19 Pandemisi: Psikolojik Etkileri ve Terapötik Müdahaleler”. İstanbul Ticaret Üniversitesi Sosyal Bilimler Dergisi, 37, Covid-19 Özel Sayıs1, 304-318.

7. Dahlqvist, V, Eriksson, S, Glasberg, A.L, Lindahl, E, Lützén, K, Strandberg, G, Söderberg, A, Sørlie, V. and Norberg, A (2007). "Development of The Perceptions of Conscience Questionnaire". Nursing Ethics, 14 (2), 181-193.

8. Glasberg, A.L, Eriksson, S, Dahlqvist, V, Lindahl, E Strandberg, G, Soderberg, A. and Norberg, A. (2006). "Development and Initial Validation of the Stress of Conscience Questionnaire". Nursing Ethics, 13 (6), 633-648.

9. Cleary, M. and Lees, D. (2019). "The Role of Conscience in Nursing Practice". Issues Mental Health Nursing, 40 (3), 281 283.

10. Mayer, J.D, Salovey, P. and Caruso, D.R. (2004). "Emotiona Intelligence: Theory, Findings, and Implications". Psychological Inquiry, 15 (3), 197-215.

11. Tarhan, N. (2019). Mesnevi Terapi. İstanbul: Timaş Yayınları.

12. Akt1, Ü, Giderler, C, Duran, C, Behdioğlu, S. ve Boz, D (2017). "Vicdani Zekâ Ölçeği: Geçerlilik ve Güvenirlik Calışması". İslam Medeniyeti Araștırmaları Dergisi, 2 (3), 329. 349.

13. Arslanoğlu, A. and Tabur, A. (2019). "The Effect of Conscientious Intelligence on the Ability to Manage Patient Expectations: Example From a University Hospital". Medicine Science, 8 (4), 1017-24.

14. Urgan, S. (2020). "Gönüllü Hizmetlerde Vicdanî Zekânın Yaşam Tatmini Ve İş Performansına Etkisi: Eskişehir Akut Örneği”. Busıness \& Management Studies: An International Journal, 8 (3), 2727-2749.

15. Sengül, H. ve Bulut, A. (2020). "Bir Vakıf Üniversitesinin Sağlık Bilimleri Fakültesinde Okuyan Öğrencilerin Vicdani Zekâ Seviyelerinin Analizi”. Turkish Studies-Social, 15 (6), 3131-3148.

16. Boz, D, Duran, C. ve Narin, İ. (2019). Vicdanî Zekânın İş Performansı ile İlișkisi: Kamuda Örnek Bir Uygulama. Ankara: Gece Akademi.

17. Juthberg, C, Eriksson, S, Norberg, A. and Sundin, K. (2007). "Perceptions of Conscience in Relation to Stress of Conscience". Nursing Ethics, 14 (3), 329-343.

18. Ahlin, J, Lidman-Ericson, E, Norberg, A. and Strandberg, G (2015). "A Comparison of Assessments and Relationships of Stress of Conscience, Perceptions of Conscience, Burnout and Social Support between Healthcare Personnel Working at Two Different Organizations for Care of Older People". Scandinavian Journal of Caring Sciences, 277-282.
19. Juthberg, C, Eriksson, S, Norberg, A. and Sundin, K. (2010). "Perceptions of Conscience, Stress of Conscience and Burnout Among Nursing Staff in Residential Elder Care". Journal of Advanced Nursing. 1708-1718.

20. Juthberg, C, Eriksson, S, Norberg, A. and Sundin, K. (2008) "Stress of Conscience and Perceptions of Conscience in Relation to Burnout Among Care-providers in Older People". Journal of Clinical Nursing, 17 (14), 1897-1906.

21. Glasberg, A, Eriksson, B. and Norberg, A. (2008). "Factors Associated with 'Stress of Conscience' in Healthcare". Scandinavian Journal of Caring Sciences, 22 (2), 249-258.

22. Altunşık, R, Coşkun, R, Bayraktaroğlu, S. ve Yıldırım, E. (2010). Sosyal Bilimlerde Araştırma Yöntemleri. Sakarya: Sakarya Yayıncılık.

23. Glasberg, A.L, Eriksson, S. and Norberg, A. (2007). "Burnout and Stress of Conscience among Healthcare Personnel". Journal of Advanced Nursing, 57 (4), 392

24. Sonmaz, S. (2002). Problem Cözme Becerisi ile Yaratıcılık ve Zekâ Arasındaki İlişkinin İncelenmesi. Yüksek Lisans Tezi, Marmara Üniversitesi Eğitim Bilimleri Enstitüsü, İstanbul.

25. Alpullu, A, Uslu, A. ve Demir, G. (2010). "Beden Eğitimi Öğretmenlerinin Duygusal Zekâ Farkındalıklarının İncelenmesi”. 01-03 Kasim 2010 Uluslararası Spor Kongresi, Ankara

26. Çoban, B, Karademir, T, Açak, M. ve Devecioğlu, S. (2010). "The Emotional Intelligence of Students Who are Sitting a Specialability Examination". Social Behavior and Personality, 38 (8), 1123-1134.

27. Gujjar, A.A, Naoreen, B, Aslam, S. and Khattak, Z.I. (2010). "Comparison of the Emotional Intelligence of the University Students of the Punjab Province". Procedia Social Behavioral Sciences, 2, 847-853.

28. Adiloğulları, İ. (2011). "The Teachers level of Emotional Intelligence Some of the Demographic Variables for Investigation". Educational Research and Reviews, 6 (13), 786792.

29. Kalantarkousheh, S.M, Nickamal, N, Amaollahi, Z. and Dehghani, E. (2014). "Spiritual Intelligence and Life Satisfaction among Married and Unmarried Females." Open Journal of Social Sciences, 2, 172-177.

30. Drahma R.S. and Kanaga, L. (2014). "Relationship Between Spiritual Intelligence and Job Satisfaction-A Conceptual Study". Global Journal for Research Analysis, 3 (3), 95-97.

31. Ravikumar, T. and Dhamodharan, D. (2014). "Impact of Spiritual Intelligence on Organizational Commitment and Job Satisfaction of Employees in Banking Sector". The International Journal Research Journal of Economics \& Business Studies, 5 (3), 1-9.

32. Kalantarkousheh, S.M, Sharghi, N, Soleimani M. and Ramezani, S. (2013). "The Role of Spiritual Intelligence on Organizational Commitment in Employees of Universities in Tehran Province, Iran". Procedia-Social and Behavioral Sciences, 140, 499-505.

33. Savaş, A.C. ve Çobanoğlu, N. (2016). "Öğretmenlerin Ruhsal Zekâsı ve Örgütsel Bağlılıkları: İs Memnuniyetinin Aracılık Rolü”. Bartın Üniversitesi Eğitim Fakültesi Dergisi, 5 (2), 496 511.

34. Aydıntan, B (2009) "Ruhsal Zekânın Dönüștürücü Liderlik Üzerine Etkisini Araştıran Uygulamalı Bir Çalışma”. Atatürk Üniversitesi İktisadi ve İdari Bilimler Dergisi, 23 (2), 257-274.

35. Akgemci, T. ve Bekiș, T. (2013). Liderlikte Ruhsal Zekâ Üzerine Bir Alan Araştırma. Selçuk Üniversitesi İktisadi ve İdari Bilimler Fakültesi Sosyal ve Ekonomik Arastırmalar Dergisi, 13 (26), 283-300. 